\title{
"SUBJECT," "CITIZEN," "NATIONAL," AND "PERMANENT ALLEGIANCE"
}

\author{
MAXIMILIAN KOESSLER+
}

So long as nations retain sovereignty, while persons move or engage in transactions across geographic boundaries, the solution of many legal problems will require concepts hinged on the relation of individuals to governing states. ${ }^{1}$ The purpose of the ensuing discussion is analysis of the key terms involved in determining the international status of persons: "subject," "citizen," "national," and "permanent allegiance."

\section{SubJect versus Citrzen}

Before the Declaration of Independence, "subject" and "denizen" " were the terms most frequently used in the United States in connections where "citizen" would now be the proper word. This was the natural usage in what then were British colonies, endowed with all the trimmings of the British legal order. Even after the Declaration of Independence, some states enacted constitutions designating as "subjects" the status which others identified by the term "inhabitants," while still others used "citizens" and "subjects" indiscriminately. "Subjects" of the United States of America were referred to in the treaties signed by the Continental Congress with France (February 6, 1778) 4 and the Netherlands (October 8,1782$).{ }^{5}$ Although the term "citizen"

$\dagger$ Attorney with War Crimes Branch, United States Army; former member of tho Vienna bar.

1. It has been predicted that most postwar claims will involve issues of nationality. Hanna, Nationality and War Claims (1945) 45 CoL. L. REv. 301.

2. "Denizen," in English law, covered the status of alien-born individuals who had been naturalized by letters-patent of the King. They were English subjects ex dontitione regis, or donaisons, hence "denizen." The right of the Crown to grant letters of denization subsisted after the British Nationality and Status of Aliens Act of 1914 (4 \& 5 GEo. V, c. 17). See Case of Fries, 9 Fed. Cas. No. 5126, at 835 (C. C. D. Pa. 1799) (treason) for a discussion, by Circuit Justice Iredell, of the concept of denizen. And see 1 PIGgort, Nationsurty (1907) 90; Chase, American Students' Blackstone (4th ed. 1914) 122; 1 Oppenueis, INTERNATIONAL LAW (Lauterpacht's 5th ed. 1937) 526, n. 3.

3. McGovney, American Citizenship (1911) 11 CoL. L. Rev. 231, 236-7.

4. 1 Malloy, Treaties (1910) 468, especially Arts. I, IV.

5. 2 Malloy, Treaties (1910) 1233 , especially Arts. II, III. This agreement between two nations with republican forms of government referred on the one hand to "the subjects and inhabitants of the United States of America," on the other hand to "the subjects of the said States General of the United Netherlands." However, the Treaty of Paris of Sept. 3, 1783, marking the official termination of the war between this country and Great Britain, contained a discriminating terminology on the point involved. It referred to the "subjects of Great Britain" and to the "citizens of the United States." 1 Mallox, TrEaties (1910) 586, Art. VIII. 
appears as early as 1777 in the Articles of Confederation, ${ }^{\circ}$ the use of "subject" as a synonym did not become obsolete before the enactment of the Federal Constitution (1787), which referred to citizens exclusively, both in relation to the United States and to the several states.' This change of usage resulted from an emerging political philosophy which abhorred any tinge of colonialism. "The term "subject" was brushed aside as a leftover from the feudal law, ${ }^{9}$ where it referred to the vassals of a lord, bound by the duty of allegiance to respect him as their master. ${ }^{10}$ However, one of the ingredients of the feudal theory of subjection survived: the concept of allegiance still forms a tautological

6. Art. IV, Articles of Confederation (precursor of the privileges and immunities clause of the present federal constitution), quoted by Cosssiger (ed.), Docusrests of AdERICAN History (2d ed. 1940) 111. See also Radin, The Aulhenlicaled Full Faills and Credit Clause: Its History (1914) 39 ILL. L. REv. 1.

Concerning the privileges and immunities of citizens of the United States as distinguished from privileges and immunities of citizens of the several states, see Newman, $A$ Forgotten Right of United States Citizenship (1945) 39 ILL. L. REv. 367. And see Slaughter-House Cases, 16 Wall. 36 (U.S. 1873); Hague v. CIO, 307 U.S. 496 (1939); Edwards v. California, 314 U.S. 160 (1941), discussed by Rostow, The Japamese American Cases-A Disaster (1945) 54 Yale L. J. 489, 500, who cites Meyers, Federal Privileges and Inmunities: Application to Ingress and Egress (1944) 29 CoRN. L. Q. 489.

7. McGovney, loc. cit. supra note 3 .

8. The general temper of that epoch is characterized by the perhaps apoeryphal story of the plan to abandon English as the American language. Mifacken, Tre Aurerican LaNGUAGE (1st ed. 1919) 36.

9. The Revolutionary attitude toward the feudal law is exemplified by the statement "Since the promulgation of Christianity, the two great systems of tyranny ... are the canon and the feudal law. ..." Hollts (ed.), The True Sentmient of Avierica (1768) 111, 113, ascribed to John Adams by WARREN, History of THE AMrericax Bar (1911) 334.

The tendency to abandon feudal concepts in this field was not limited to America. The terms citoyen and cittadino, respectively constituting the French and Italian versions of "citizen," supplanted "subject" in those countries, with the qualifications discussed injra note 45 and related text. In Austria, Unterlan, or subject, was replaced by Slaatsbuserger (citizen). However, the phrase sujets mixtes (mised subjects), at least in European technical usage, and probably also in this country, is the preferred designation of the status of percons" with multiple nationality.

10. "Allegiance is the tie, or ligamen, which binds the subject to the ling, in return for that protection which the hing affords the subject . . . the name and the form are derived to us from our Gothic ancestors." I BL. Cosar. "366. See also Calvin's Case, 7 Co. 1a, 53 (77 Eng. R. 377, 382, K. B. 1608) where it is said with reference to Glanville that "as between the Sovereign and subject there is duplex el reciprocum ligamen; quio sicul subdius regi tenetur ad obedientiam, ita rex subdito tenetur ad protectionem. . . ." Follows then the famous passage: "Therefore it is truly said that protectio tralit subjectionem, ct subjettio protectionem." And see Dicey, A Digest of the Law of ENGLand with Reference to tae Consutct of Laws (Keith's 5th ed. 1932) 896-7; BrierLy, The Law of Nations (3d ed. 1942) 3-4. The orthodox theory of the reciprocal connection between allegiance and protection, although of doubtful reasoning, is vindicated in the otherwise startling doctrine enunciated in the treason case against "Lord Haw-Haw," Rex v. Joyce, 62 T. L. R. 57 (Ct. Cr. App. 1945); (1946) 46 Col. L. REv. 319. 
part ${ }^{11}$ of our statutory definition of nationality. ${ }^{12}$

The term "citizen" supplanted "subject" in this country and others, although not in Great Britain, ${ }^{13}$ by a process of lexicographic delineation. Even in the period immediately before the American Revolution, there was no such difference in connotation between "subject" and "citizen" as would predicate reserving the status of "citizen" to the people of a republic and "subject" to those under the sovereignty of a monarch. Distinguished French lawyers, writing during the ancien régime, seem to have found nothing preposterous in their occasional use of the term "citizen" with regard to the most absolutistically ruled subjects of the King of France. ${ }^{14}$ During the middle ages, "citizens" lived in towns, and so were members of communities exempted from the then almost ubiquitous feudal system. ${ }^{15}$ But, when the medieval system of government was replaced by the principles of territorial state sovereignty, "subject" and "citizen" came to be used as synonyms, at least by such eminent writers as Bodin ${ }^{16}$ and Grotius, ${ }^{17}$ although

11. In Baumgartner v. United States, 322 U. S. 665, 673 (1944), Mr. Justice Frankfurter, per curiam, after citing Schneiderman v. United States, 320 U. S. 118 (19.13), and similar cases, announced:

"Allegiance to this government and its laws, is a compendious phrase to describe those political and legal institutions that are the enduring features of American political society. We are here dealing with a test expressing a broad conception - a breadth appropriate to the nature of the subject matter, being nothing less than the bonds that tie Americans together in devotion to a common fealty." And see note 68 infra.

12. Sec. 101(a) of the Nationality Act of 1940,54 Stat. 1137, 8 U. S. C. $\S 501$ (1940) reads: "The term 'national' means a person owing permanent allegiance to a state." Sec. 101 (b) elucidates: "The term 'national of the United States' means (1) a citizen of the United States, or (2) a person who, though not a citizen of the United States, owes permanent allegiance to the United States. It does not include an alien." The final phrase is cryptic. If "alien" means one who is not a national, the phrase is surplusage. If "alien" means one who is not a citizen, it is inconsistent with the fact that the Act establishes the possibility of nationality without citizenship. Quaere: Is there any third way of understanding that phrase?

13. "'British subject' is an inclusive term, denoting all subjects of His Britannic Majesty, to whatever part of the Commonwealth they may belong. The term 'citizen' is applied to a person in respect of whom a particular member of the Commonwealth claims jurisdiction." Stewart, Treaty Relations of the Brutish Commonwenltil of Nations (1939) 384.

14. See, e.g., 3 D'Aguesseau, Oevvres (1762) 117, 129, 130, 138. Pothier used the term citoyen even with regard to the class of serfs. 5/I. Dupin (ed.), PothIER, OEuvkes (Traite Des Personnes) (1831) Tit. $1, \S 4$.

15. Carr, The General Principles of the Law of Corporations (1905) 146, teprinted in 3 Select Essays in ANglo-Anterican Legal History (1909) 161, 180, and McGovney, supra note 3, at 235.

16. Bodin, Les Six Livres de LA REPUBLIQue (1576) Bk. 1, c. 6, conceives a ciloytn as a free sujet under another person's sovereignty.

17. Grotius, De Jure Belli Ac Pacis (1646), e.g., in Bk. 2, c. 25, indificrently uses civis or citizen and subditus or subject, as designations of the same status. Similarly, Hondes, 
others, including Pufendorf ${ }^{18}$ and Spinoza, ${ }^{19}$ obviously inspired by a passage in Aristotle's Politics, ${ }^{20}$ attempted to re-establish a distinction between those two terms.

Spinoza's abstractions remained without direct practical effect, until a passage in Rousseau's Social Contract, adapting and somewhat coloring, but not quoting, Spinoza's proposition, ${ }^{21}$ provided the stimulus which made "citizens" the terminology for a self-governing people..2 An English version of the passage reads, "With regard to the associates, they take collectively the name of People, and are individually called Citizens, as participating in the sovereign power, and Subjects, as subjected to the laws of the state." 23

\section{Nationality as the Status of Belonging to a State}

"Nationality" is a young word. Its matrix, the French nationalite, appeared for the first time in the 1835 edition of the Diclionnaire de l'Académie Française. ${ }^{24}$ It has at least two accepted denotations: (1) the status of belonging to a state; (2) the quality of membership in an ethnological group. ${ }^{25}$ Nationality in the sense of belonging to a state

Elensenta Philosophica DE Cive (1616) c. 5, $\S 6$, says (writer's translation), "Each citizen, as well as each dependent corporation, is in relation to the holder of the sovereignty called a subject." Even a century later, VATrel, LE Droir Des Gess (1758) Bl. 2, c. 3, $\S 107 ;$ Bk. 3, c. $1, \S 8$ used "citizen" and "subject" as synonyms.

18. Pufendorf, Elementoruat Jurisprudentiae Univers.ilis Libri Deo (1672) Bk. 1, Def. 3, §9; Def. 8, §4; Def. 12, §6; De Jure Naturae et Gentiust Libri Octo (1698) Bk. 7, c. 2, § 20; De Officio Hoarinis Et Crvis Juxta Legeas Naturaleus Libri Duo (1673) Bk. 2, c. 6, $\$ 13$.

19. Sprnoza, Tractatus Politicus (1677) c. 3, said: ". . . [W]e call men Citizens, as far as they enjoy by the civil law all the advantages of the commonwealth, and Subjects, as far as they are bound to obey its ordinances or laws." 1 ELwES (tr.), THE Cares IVorks of Benedict De Sprnoza (rev. ed. 1900) 301.

20. "A citizen . . . is defined by nothing else so much as by the right to participate in judicial functions and in office . . the definition of a citizen that we have given applies especially to citizenship in a democracy; under other forms of government it may hold good, but will not necessarily do so." Arrstothe, Polrtrcs (Rackham's trans. 1932) Bli. 3, c. 1. For the impact of this definition upon the Defensor Pacis (1324), sec 2 Scotr, Law, The State and the Internatronal Comaruntry (1939) 190. But $c$. critical comments by Bodin, loc. cit. supra note 16.

21. According to Dreyfus-Brisac's note, in his edition of Roussenu's Co:trant Socral (1896) 354, 356.

22. Jellinek, Allgejeine StaAtslegre (1900) 366-7.

23. Contrat Social Bk. I, c. 6, contained in Andretys, Ideal Eurpires and RePUBLICS (1901).

24. Cogordan, la Nationalite (1879) 2, n. 1; 3 Littré, Dictioniame de la LANGUE FrançaIse (1869) 692.

25. This duality of meaning derives from the parent-word, "nation." Contrast the answers to the question "What is a Nation?" The French Revolutionist, Abbe Sieyes, as quoted by Sulzback, National Consciousness (1943) 63, answered, "A body of associates living under one common law and represented by the same legislature." He obviously pointed to statehood. RENAN, QU'EST-CE QU'UNE NATION? (1882) 27, suggested (writer's 
is a primarily legal concept, the existence of which in a certain person will be determined by such extrinsic tests as the applicable law prescribes. Nationality, ethnologically, while essentially a sociological conception with political implications, ${ }^{26}$ may occasionally have a palpable legal effect. ${ }^{27}$ Determination of ethnological nationality in a given case may be a touchy matter, since the standards are not universally recognized and are, at least partly, subjective rather than objective.

In its legal sense, the term "national" is often used as a general designation irrespective of whether the status of belonging to a state is examined with a view to certain rights and (or) duties under international law, or is looked upon as the basis of rights and duties, effective within the domestic sphere of a state. However, the trend is to reserve the term "national" for the designation of that status by virtue

translation): "The existence of a nation is a daily plebiscite." He certainly meant nation in the ethnological sense of the word, as did Shakespeare's Shylock: "He hates our sacred nation." The Merchant of Venice, Act I, Scene 3. See Guerard, The France of TOMORRow (1942) 33. In general see Hayes, Ess̀ays on NationalisM (1926) 4, 5; 2 WRIGHT, A StUdy OF WAR (1942) 996-7.

26. "Nationalism" may perhaps be described as the dynamic trend of a nation in the ethnological sense of the word to become a nation in the sense of independent stateltood. See Maciver, Society, A Textbook of Socrology (1937) 155. Compare Mancini's lecture, Nationality as the Foundation of the Law of Nations (1851), reprinted, Maraunem (ed.), Diritto Internazionale Di P. S. Mancini (1873) 1, with Lord Acton, Nalionality (July, 1862) Home and Foreign Review, reprinted, Figgis and Laurence (eds.), Joirn Emerich Dalberg-Acton (Lord Acton), The History of Freedom and OtHer Essays (1922) 270. See Hayes, Essays on Nationalism (1926) 4, 5; Cark, Conditions of Peace (1942) 64-5; Hula, National Self-Determination Reconsidered (1943) 10 Soc. REs. 1; Friedmann, The Disintegration of European Civilization and the Future of Intcrnational Law (1938) 2 Mod. L. REv. 194, 197.

27. Under Art. XIX of the Austrian constitution of 1867 [HUGELManN, DAs NAtronALITÄTENRECBT DES ALTEN ÖsTERREICH (1934) 81-2], ethnological groups in the Austrian Empire were supposed to receive equal treatment in certain specified respects. Under Art. 80 of the peace treaty of St. Germain, the right of option among the succession-states of the Austrian monarchy depended to a measurable extent upon the ethnological quality of the optant. Again, in the case of modern forced exchange of populations, the "nationality" of a person carries radical legal consequences. According to Art. 2 of the German decree on the "Protectorate" of Bohemia and Moravia, March 16, 1939, the inhabitants of the Protectorate, who theretofore were Czechoslovakian citizens, became citizens of the Reich, if they were of German "nationality," otherwise citizens of the Protectoratc. Sce Jones and Myers (eds.), Documents On American Foreign Relations (1939) 290-301. By the German-Hungarian Protocol of August 20, 1940 (1941) 24 ZEITsCHRIFT FUR VöLKERRECHT 456, Hungary "acknowledged" the claim of the Reich to exercise protection over those inhabitants of Hungary, irrespective of their citizenship, who belonged to the German Volksgruppe (ethnological group) and were recognized as such by the leader of the German Volksbund, a Germano-nationalistic organization in Hungary. On this "agreement" and similar German treaties for the protection of the folk group (Volksgruppenschutzvertrilge), see Murpey, National Socialism [U. S. Dep't of State, Pub. No. 1864 (1943)] 140-4. For the related topic of minority-treaties, see 1 SchWARZENBERGER, INTERNATIONAL LAW (1945) 111-2 et seq. 
of which a person, internationally, belongs to a certain state, and to speak of "citizenship" when the local status referred to is one of domestic rather than international law.

\section{Citizenship versus Natronality}

"Citizenship," in modern usage, is not a synonym of nationality or a term generally used for the status of belonging to a state, but means specifically the possession by the person under consideration, of the highest or at least of a certain higher category of political rights and (or) duties, established by the nation's or state's constitution. This conception, substantially amounting to a modern revival of an Aristotelian formulation, is defined by Moore: "Citizenship, strictly speaking, is a term of municipal law, and denotes the possession within the particular state of full civil and political rights, subject to special disqualifications, such as minority or sex. The conditions on which citizenship is acquired are regulated by municipal law." 23 However, since the list of the concrete rights and duties, that constitute "citizenship" in this specific sense, differs according to the country in question, it has also been said, ". . . [T]here is no universal definition of citizenship when citizenship ceases to be synonymous with nationality." :

Applications of "citizen" in the narrower sense, along the lines of Moore's definition, have occurred chiefly in connections where domestic status of nationals vary. The Mexican law apparently considers such special disqualifications as are inherent in minority as inconsistent with the concept of citizenship as distinguished from nationality..$^{\circ}$ In the United States there has been an issue as to whether the so-called "alien-vote," which for a time existed in certain states, "was tanta-

28. 3 Moore, Digest of INternational LaW (1906) 273. See 2 Hyde, INTERnatio:ML LAw (rev. ed. 1945) 1066-7, n. 6; 3 Hackworte, Digest of International. Law (1942) 1; Harvard Research in International Law, Nationality: Responsibility of States: Territorial Waters (1929) 23 A3r. J. INT. L. SPEC. Supp. 24; Flournoy, Nationality (1933) 11 Excrc. Soc. Sciences 2:19; Gettys, The Law of Citizensuip in tue United Stites (1934) 3; McGovney, Our Non-Citizen Nationals, Who Are They? in Rudis axd KIDd, LEG.AL Ess.1Ys (1935) 323; Wilson, Gradations of Cilizerstip (1939) 33 Asr. J. Isr. L. 146. An outstanding German monograph on the modern distinction between nationality and citizenship (Staats-

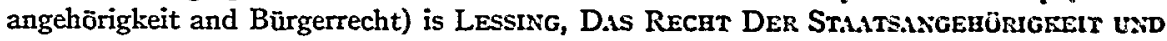
DIE ABERKENNUNG DER STA.ATSANGEHöRIGKEIT ZU STRMF- UND SICHERUNGZWECEE: (1937). A pertinent discussion by a South-American scholar is: 2 MIORExo QurvriNa, El Siste:ra INTERNACIONAI AMERICANo (1926) 314-5.

29. MicGovney, supra note 3 , at 235.

30. Law of Nationality and Naturalisation of January 19, 1934, repealing the lex Vallarta of May 28, 1886. See Koessler, The Reformed Mexican Nationdily Lrw (1943) 5 LA. L. REv. 420 . In order to be a citizen, a Mexican must be over twenty-one years of age if not married and over eighteen years if married, with the further requirement, in either case, that he possesses the means of a decent living.

31. The alien vote existed as late as 1926 in Arkansas. See Aylsworth, The Pussing of Alien Suffrage (1931) 25 Asr. PoL. Scr. Rev. 114. For a contemporary survey of the various 
mount to the possession of citizenship, a question which seems to have been finally decided in the negative. ${ }^{32}$ A similar dispute arose with regard to a somewhat reverse proposition, namely, that since women may be citizens in this country, they should as such be entitled to the suffrage. While the Supreme Court of the United States decided in the negative, ${ }^{33}$ an amendment to the federal constitution satisfied the claim of the feminists. ${ }^{34}$

The first precedent in the line of republican constitutions which used the term "citizen" substantially in the narrower sense, seems to be represented by the French constitutions of 1793, 1795 and 1799, 30 which, in contrast to the French constitution of 1791, distinguished between a Français generally and a citoyen. The latter term designated the Frenchman who possessed the qualifications prerequisite to the vote. ${ }^{36}$ Citizenship in this sense was also mentioned in the original Code Napoléon. ${ }^{37}$

For a time during the nineteenth century, there was a tendency in France to distinguish between two kinds of naturalization. Grande naturalisation conferred the legal position of a citoyen; petite naturalisation made the former alien a Frenchman without the right to vote. ${ }^{38}$ In this country, limited distinctions exist between the status of born and naturalized citizens in that only a born citizen may become President ${ }^{39}$ or Vice-President ${ }^{40}$ of the United States, while a naturalized citizen may expatriate himself by extended residence abroad. ${ }^{41}$

state laws on the alien vote see BERNHEIM, THE History OF THE LAW OF ALIENS FroN THIE STandpoint of CoMiparative Jurisprudence (1885) 150.

32. Lanz v. Randall, 14 Fed. Cas. 1131 , No. 8,080 (C. C. D. Minn. 1876); Minneapolis v. Reum, 56 Fed. 576 (C. C. A. 8th, 1893); Petition of Sproule, 19 F. Supp. 995 (S. D. Calif. 1937).

33. Minor v. Happersett, 21 Wall. 162 (U.S. 1874).

34. U. S. Const. AMrend. XIX.

35. Printed in Duguit and Monnier, Les Constitutions ex les Principales Lors Politiques de la France Depuis 1789 (3rd ed. 1915) 66, 78, 118.

36. McGovney, Frenich Nationality Laws Imposing Nationality at Birli (1911) 5 Ass. J. INT. L. 325, 327.

37. Prior to the amendment of 1889 , Art. 8 referred simply to a Frenchman (Français), while Art. 7 referred to the capacity of a citizen (qualite de citoyen), and provided that the exercise of civil rights should be independent therefrom. In view of the influence of French law upon the legal developments in Latin-American countries, it is fair to assume that constitutional provisions in those countries which employ the term "citizen" in a narrower sense may be traced to the French constitutions. See 2 Moreno Quintana, loc. cil. supra note 28.

38. Ancel, The French Law of Naturalization (1936) 10 Tulane L. Rev. 231, 234.

39. U. S. Const., Art. II, $\S 1$.

40. U. S. Const. ANend. XII.

41. The Nationality Act of 1940 provides for loss of nationality by naturalized Americans who reside abroad for extended periods under specified conditions. 54 STAT. 1170, 8 U. S. C. $\$ \$ 804$ et seq. (1940). The previous statute created only a rebuttable presumption of voluntary expatriation. 34 STAT. $1228-9$ (1907), 8 U. S. C. $\$ 17$ (1940). Such loss of 
Hitler's Secretary of State for the Interior, Stuckart, suggested as an anti-Semitic device the Nuremberg laws, which established a gradation among those who were simply Staatsangehörigen or nationals of the Reich, and those who possessed the racial qualities which were required for the possession of the privileged status of Reiclssbiirger or citizen of the Reich. ${ }^{42}$ These laws substantially duplicated the sixteenthcentury Spanish enactments, instigated by the Inquisition, which made the possession of Christian blood a requirement for the status of civis pleni juris or full citizenship. ${ }^{43}$

\section{Citizen versus Colonial Subject; the Adrerican Non-Citizen National}

An application of political ethics not to be confounded with racial discrimination is a gradation of nationality employed by a country standing on a high level of civilization, which attaches to its sovereignty a territory with a backward population, to avoid granting the latter a full share in the self-government of the former. ${ }^{44}$ For this reason

nationality should not be confused with revocation of nationality under 8 U. S. C. $\S 738$, where naturalization was fraudulently procured. By $\$ 738$, removal abrozd within five years of naturalization is prima facie evidence of a lack of intention, at the time of naturalization, to become a permanent citizen of the United States.

The constitutionality of the current provisions for loss of nationality has not been passed on by the courts, and earlier cases [see, e.g., Luria v. United, States, 231 U. S. 9 (1913)] dealing with cancellation of naturalization under older laws are not necessarily in point. For a discussion of the problem, as it stood before the Nationality Act of 1940, ere Flournoy, Revision of Nationality Laws of the Untiled States (1940) 34 Ass. J. INr. L. 36, 40-5. And see Osborn v. United States Bank, 9 Wheat. 738, 827 (U. S. 1824); United States v. Wong Kim Ark, 169 U. S. 649, 703 (1898); Johannessen v. United States, 225 U. S. 227, 241 (1912); Schneiderman v. United States, 320 U. S. 118 (1943); Baumgartner v. United States, 322 U.S. 665 (1944); Knauer v, United States, 66 Sup. Ct. 1304 (U. S. 1946). Related discussions are: Preuss, Denaluralization on the Ground of Disloyalty (1942) 36 Arr. PoL. Scr. Rev. 701; Cable, Loss of Citizenseip: Denaturalization: The Alien la War-The (19:3) 12; Stein, Rerocation of Citizenship- "Denaluralization" (1914) 28 Mare. L. REv. 59; Burle, Interpretative Results of Wartime Denaturalisalion Proceedings (1944) 18 So. CaLIF. L. REv. 110; Note, Recent Trends in Denaturaliantion in the United Slates and Abrosd (1944) 44 CoL. L. REv. 736; Balch, Denaturalization Based on Disloyalty and Disbelief in Constitutional Principles (1945) 29 MrNN. L. REv. 405.

42. Garner, Recent Germanz Nationality Legislation (1936) 30 Aus. J. Ist. L. 96; JAxowsKy and Fagen, International Aspects of Gerasun Racul Policies (1937) 142-3; Loewenstein, Gozernment and Politics in Germany in Skotweld, Governuents of ContrNENTAL EUROPE (1940) 514. For a Nazi view, see Koellreutter, Grandfragen unserer Voltsund Staatsgestaltung in Meier-Benneckenstein, Schriftender Deutsches Hocrscrure FÜr PoLITIK (1936).

43. De Los Rios, Spain in the Epoch of American Colonizalion in Grarsin (ed.), CosCERNING LATIN AMIERICAN CULTURE (1940) 25, 40-2.

44. The rationale is that the backward people must be "educated" to the art of self government. Kelsen in one of his earlier works considered this gradation inconsistent with democracy, as then defined by him. Kelsen, Allgeareine Stantslegrre (1925) 161. 
France and Italy distinguish between a citizen and a colonial subject. ${ }^{40}$

The Nationality Act of 1940 sanctions the distinction between American nationality, including American citizenship, and American nationality, devoid of American citizenship. ${ }^{46}$ In terms of this statute, American citizenship embraces in addition to those privileges and (or) duties which are inherent in American nationality, such as the possibility of diplomatic protection by the United States ${ }^{47}$ and the body of obligations customarily referred to as "permanent allegiance," 48 the existence of those rights which only a "citizen" enjoys under the Constitution. However, even recent legislation occasionally uses the term "citizen" in a wider sense embracing any American national. ${ }^{40}$

Filipinos, before the independence of the Philippine Islands, are the most conspicuous recent specimen of American non-citizen nationals. ${ }^{60}$ It has been suggested that before a special statute made American Indians citizens, they should have been considered non-citizen nationals of the United States. ${ }^{51}$ Lawyers who at an earlier period of American

45. See 1 Niboyet, Traite de Droit Internatronal Prive Franģais (1938) 93; 2 id. at 2, 3; Royal Institute of International Affairs, The French Colonial Eupine (Information Dep't Paper No. 25, London, 1940) 27; Royal Institute of INTERnational. Affairs, The Italian Colonial Expree (Information Dep't Paper No. 27, London, 1940) 55; Valeriani v. Amuna Bekri Sichera, 1935-1937 Annunl Dig. ANd Rep. of Puv. INT. L. CAs. 283 (1935). The discussion of an analogous phenomenon in the Kingdom of the Netherlands by François, Le Probleme des A patrides (1935) 53 (III) ACAdtaire DE Droit INTERNATIONAL, RECEUIL DES CouRs 283,290 , is probably antiquated, in view of later developments.

46. See note 12 supra. In Mixed Clatus Commission, United States and Gersany, Administrative Decisions and Opinions to June 30, 1925, Administrative Decision No. $V$ (October 31, 1924) 193, the following rule was laid down:

"The term 'American national' means a person wheresoever domiciled owing permanent allegiance to the United States of America, and embraces not only citizens of the United States but Indians and members of other aboriginal tribes or native peoples of the United States and of its territories and possessions."

See also HACKWORTH, loc. cit. supra note 28.

47. However, "protection may always be extended or withheld at the discretion of the Secretary of State." Jessup, Revising Our Nationality Laws (1934) 28 As. J. INT. L. 104, $10 \%$.

48. But see discussion infra, p. 67 et seq.

49. "Citizen," as used by the Neutrality Act of 1939, included "any individual owing allegiance to the United States. . . "54 STar. 12 (1939), 22 U. S. C. $§ 456$ (1940). Within the meaning of this particular statute Filipinos, otherwise non-citizen nationals, wero "citizens." See Suspine v. Compania Transatlantica Centro-Americana, S. A., 37 F. Supp. 268, 270-2, 1941 Am. Mar. Cas. 356, 360-2 (S. D. N. Y. 1941).

50. See Hayden, The Phulppines: A Study in National Development (19:12) 771, especially (on the Tydings-McDuffie Act) 807-8. For a recent judicial discussion of the status of the Philippine Islands in general, see Hooven \& Allison Co. v. Evatt, 324 U. S. 652, 668,677 (1945).

Need for new applications of this category may arise with regard to the native population of permanent bases acquired by this country following World War II.

51. McGovney, op. cit. supra note 28, at 344 . See also the Administrative Decision No. V of the Mixed Claims Commission, United States and Germany, note 46 sulpra. But cf. Ex parte Crow Dog, 109 U. S. 556 (1883); Elk v. Wilkins, 112 U. S. 94 (1884); discugsion by Priest, UNCLe SAM'S StEPChIDREN (1942) 198. 
history denied to native-born free Negroes the status of American citizens ${ }^{52}$ but nevertheless held them eligible for the diplomatic protection of this country ${ }^{53}$ seem not to have realized the technical possibility of construing their status as that of non-citizen nationals, although, with regard to declarant aliens or aliens with First Papers, ${ }^{54}$ Secretary of State Marcy, in his note of September 26, 1853 concerning the Koszta affair, appears to have raised the point that a person may be a national of the United States, without being an American citizen..$^{55}$ The prevailing opinion seems to be that declarant aliens are not American nationals, since it has been settled that they are not within this country's diplomatic protection, ${ }^{56}$ and those anomalies which previously singled out their conditions from that of other aliens no longer exist.

\section{Permanent Alieglance}

Reference to a duty of "permanent allegiance" is not a happy way of defining nationality in the sense of a status under international law. Such a definition envisions a specific distinction between the "permanent" relation of nationality and the "temporary allegiance" 57 required of resident aliens, ${ }^{58}$ and so keeps alive the largely-abandoned maxim "once a subject, always a subject." "59 However, a national can now generally expatriate himself, at least by naturalization in another

52. Dred Scott v. Sandford, 19 How. 393 (U. S. 1857). And see Swisrer, Aurericis Constitutional Developarent (1943) 247.

53. See the paraphrase of Secretary of State Marcy's instruction of January 18, 1855 in the case of Lucien Mateo v. Mexico, 3 Moore, International ARbitritross 2461-2. That paraphrase reads in part: ". . . [I]n the view of high judicial authority, . . . perzons of African descent could not be regarded as entitled to full rights of citizenship . . . Although . . . the consul could not certify that they were citizens of the United States, . . . he might certify that they were born in the United States and were free, and that the government would regard it as its duty to protect them, if wronged by a foreign government. ..."

54. Koessler, Rights and Duties of Declarant Aliens (1942) 91 U. oF PA. L. Rev. 321.

55. Id. at 324-5.

56. Id. at 328-9.

57. See Carlisle v. United States, 16 Wall. 147, 154 (U. S. 1872). Cf. Perkins v. Elg, 307 U. S. 325, 334 (1939), where "expatriation" is explained as "the voluntary renuncintion or abandonment of nationality and allegiance," thus apparently separating "allegiance" from "nationality."

58. See De Jager v. Attomey General of Natal (1907) A. C. 326, critically discussed by Baty's note in (1908) 33 The Lat Mlagazine and Review 214. And see Rex v. Joyce, 62 T. L. R. 57 (Ct. Cr. App. 1945), (1946) 46 CoL. L. Rev. 319, where the doctrine of allegiance was applied to an alien possessing a fraudulently obtained passport issued by the sovereign claiming allegiance.

59. England abandoned the feudal concept of indissoluble subjection by legislation in 1870. See 1 WestlaKe, INTERNaTIONAL Law (2d ed. 1910) 206, where it is said that "parmsnent allegiance" as a technical term for the tie between a state and its nationals does not mean that the tie cannot be severed, but "that so long as it continues it exists whether the national is for the moment in the territory of his state or abroad." 
state $; 00$ most states make such denationalization automatic. ${ }^{61}$ While the existence or absence of such a provision is generally a matter of domestic law, the so-called American doctrine of voluntary expatriation in effect postulates loss of original nationality on naturalization elsewhere as a principle of international law. ${ }^{62}$ The American doctrine was substantially, if not in terms, enforced by the Franco-Turkish Mixed Arbitral Tribunal after the First World War, ${ }^{63}$ although not granted acceptance at the Hague Conference of $1930 .^{64}$

The term "allegiance" in itself has become archaic. In its feudal setting, "allegiance" denoted a reciprocal correlation of interconnected rights and duties. But in modern states the obligations of the national to the nation are unconditional, rather than contingent upon the state's compliance with corresponding duties. Only in isolated instances do modern writers consider the relation between the national and his state as contractual. ${ }^{65}$ Furthermore, the national of a state is generally not entitled to claim protection as a matter of right. The state has a right, as against other states, to exercise diplomatic protection in his behalf, but not a duty toward the national. ${ }^{66}$ In this country

60. See Flournoy, Naturalization and Expatriation (1922) 31 Y $\Lambda \mathrm{LE}$ L. J. 702, 848; Flournoy, Expatriation (1931) 6 Encyc. Soc. Sciences 3; Tsiang, The Question of Expatriation in America Prior to 1907 (1942). See also Mackenzie v. Hare, 239 U. S. 299, 307 et. seq. (1915); Ex parte Griffin, 237 Fed. 445, 453 (N. D. N. Y. 1916).

61. See, e.g., Section 401(a) of the Nationality Act of 1940, 54 STAT. 1168, 8 U. S. C. $\$ 801$ (a) (1940). This is sometimes called the "French principle," because its first statitory enactment was contained in the French Constitution of September 3, 1791, Tit. II, Art. $6, \S 1$, reprinted, Duguit and MoNNIER, op. cit. supra note 35 , at 6 .

62. This American policy found the most forceful legislative expression in the Expatriation Act of July 27, 1868; 15 STAT. 223 (1868), 8 U. S. C. $\$ 800$ (1940), partly quoted by Koessler, op. cit. supra note 30 , at $427, n$. 36 . This Act has not been abrogated by the Nationality Act of 1940. For the recent repeal of a similar provision in the Mexican legislation, see ibid.

63. Apostolidis v. Turkish Government, 8 Recueil des Décisions des Tribunaux Arbia traux Mixtes 373, 375, ANNuAL Digest of Public International LAw CASEs (1927-1928) 312 (1928).

64. Flournoy, Nationality Convention, Protocols and Recommendations Adopled by the First Conference on the Codification of International Law (1930) 24 AM. J. INT. L. 467.

65. See, e.g., 1 Weiss, Drort International Privt (2d ed. 1907) 8. Contra (and in this expressing the general view): 1 Niboyet, Traite de Droit Internationat Prive FraNçars (1938) 122-3.

66. See 1 Oppenhem, International Law (Lauterpacht's 5th ed. 1937) 505. An ap. parent exception is Article 112 of the German Weimar constitution which reads "All German citizens within and without the boundaries of the Reich have the right of protection by the Reich against foreign countries." McBAIn and Rogers, The NEw Constitutions of Europe (1922) 198. This provision was literally taken from Art. 3, $\S 6$ of the previous (Imperial) German constitution, discussed in 1 LABAND, DAs SrAATSREcht des DEUTSCHEN Reiches (5th ed. 1911) 152, and n. 2. Laband believed that Art. $3, \S 6$ of the Imperial Constitution was a right, technically, of the German citizen against the Reich. See SlaughterHouse Cases, 16 Wall. 36, 79 (U. S. 1873). But see Isay, Die StaAtsangehoerigkeit JuRIstischer Personen (1907) 37. 
a definite practice has been established that in certain typical situations diplomatic protection should normally be denied in spite of the American nationality of the applicant. ${ }^{67}$

Deprived of one of the essential ingredients which went into its feudal meaning, namely of the subject's right to claim his lord's protection, and also minus the whole general background of the one-time feudal society, "permanent allegiance," referred to in a modern definition of nationality, cannot be more than a synonym for "nationality." cs It has become a mystic concept which dims, instead of clarifying, definitions. Most people have a working knowledge of the meaning of "nationality," but even scholars are at a loss to explain "allegiance." Characteristically, the Harvard Research on Nationality suggests defining nationality as "the status of a natural person who is attached to the state by the tie of allegiance," ${ }^{69}$ and then muddies the picture by saying:

"No attempt is made in this draft to define the meaning of allegiance. It may be observed, however, that the 'tie of allegiance' is a term in general use to denote the sum of the obligations of a natural person to the state to which he belongs. The draft itself does not spell out these obligations, since they are quite different in different societies." 70

It seems desirable to eliminate "allegiance" from any technical use and redefine "nationality" in plain words meaning the status of belonging to a state for certain purposes of international law. ${ }^{71}$

\section{The Dual Nature of Sovereignty}

Another source of confusion in defining nationality is the concept that state sovereignty is personal as well as territorial. ${ }^{72}$ The right-duty

67. Seckler-Hudson, Statelessness (1934) 17.

68. Under this assumption, definitions of nationality, which explain the latter by referring to "permanent allegiance," are tautological, as suggested sipra, p. 000. But they are, in this respect, not worse than some definitions not referring to "allegiance." See, e.g., 1 Piggott, Nationality (1907) 6, and 1 Oppeniens, Interamational Law (Lauterpacht's 5 th ed. 1937) 511.

69. Article 1(a) of the Harvard Draft (1929) 23 Arr. J. Irr. L., SpEc. Supp. 13.

70. Id. at 23 .

71. In passages where the English text of the Treaty of Versailles referred to "nationals," the French one did not always use the term nationaux, but sometimes synonymously employed the word resortissants which means "belonging to." Therefore Is.tY, DIE PRIVATEN RECHTE UND INTERESSEN ISI FRIEDENSVERTRAG (3rd ed. 1923) 46-7, challenged the correctness of the occasional attempt to distinguish, in the application of the Treaty of Versailles, between nationaux and resortissants. Cf. SchwarzeNBERGER, op. cil. supro note $2 \pi$, at $155-6$.

72. 1 Zitelasand, Internationales Pruvatrecat (1912) 82. Of course, these two kinds of jurisdiction are merged into one in the case of nationals residing within the national territory. 
relationship between states, with respect to a national of one, is a function of the personal sovereignty of the state over its nationals. However, the distinctions between personal and territorial sovereignty are flexible and not clearly delineated, ${ }^{73}$ so that this concept does not contribute to defining nationality as an aggregate of specified rights and (or) duties.

\section{Nationality as a Formal Category}

Nationality is a formal legal category, consisting in a person's status of belonging to a state. ${ }^{74}$ Error seems inherent in any attempt to define the conception by reference to "allegiance" or to any other specific right-duty relationship, ${ }^{75}$ inasmuch as rights and (or) duties which are attributed to the status of national, ${ }^{76}$ whether by international or domestic law, will vary geographically and temporally. The concept of nationality is no more than a formal frame, surrounding a picture of changeable character. ${ }^{77}$

For example, the most conspicuous international function of the nationality concept is the right of a state to extend protection to its nationals abroad. ${ }^{78}$ In exceptional cases a state is permitted to exercise protection over individuals not its nationals, ${ }^{79}$ or, conversely, it may be excluded from the right to protect those of its nationals who belong

73. How far a given state intends to stretch its personal jurisdiction or sovereignty with regard to nationals abroad is a matter of domestic law; whether its respective claim is justified, in relation to other states, is a matter of international law. Illustrative of the claim of the American domestic law concerning the extent of the personal sovereignty of this country over citizens abroad are Cook v. Tait, 265 U. S. 47 (1924) (taxability), and Blackmer v. United States, 284 U. S. 421 (1932) (subpoena served abroad).

74. McGovney, supra note 3, at 232-3. See also 2 Calvo, Le Drort International. (5th ed. 1896) 24; BURCkHardt, Die Organisation DER ReCHTsgemeinschaft (1927) $361-2$.

75. This is one of the errors in Lessing's definition of nationality as the relation between an individual and a state by virtue of which the latter is entitled to protect the former abroad, and is bound, in addition, to permit his residence on its territory, with the resulting prohibition of banishment of a national from the whole national territory and the resulting duty of receiving back a national deported from a foreign state. Lessing, op. cil. supra note 28 , at 148 .

76. Nationality, as distinguished from citizenship (in the narrower sense referred to supra, p. 63.) though primarily a conception with an international function, is often borrowed as a convenient attachment for certain strictly domestic purposes, as in statutory provisions making nationality a requirement for admission to certain public offices or quasipublic or even private professions. Lessing, op. cit. supra note 28 , at $148, n, 2$, in this connection speaks of an "accessory" (i.e., "secondary") effect of nationality.

77. Jellinek, Systems der Subjektiven OefFentlichen Rechte (1905) 117.

78. "One of the most important and delicate of all international relationships, recognized immemorially as a responsibility of government, has to do with the protection of the just rights of a country's own nationals when those nationals are in another country." Hines v. Davidowitz, 312 U. S. 52, 64 (1941).

79. 1 OpPenheim, InTERnational Law (Lauterpacht's 5th ed. 1937) $514 \mathrm{el} \mathrm{seq.}$ 
to a particular category. so But normally it is only through the intervention of the state of their nationality that private persons are able to obtain redress against injuries inflicted upon them by a foreign state in violation of international law. ${ }^{81}$ However, there is a trend toward permitting private persons to raise international claims without the intermediate agency of a state. ${ }^{82}$ Materialization of this proposition would render the institution of diplomatic protection obsolete, if not formally abolished. But nationality would remain a living concept as long as any legal consequences are attached to the status of belonging to a state.

As a further example, it is sometimes said-either unconditionally or with qualifications - that a country is prevented by international law from forcing military service upon nationals of another state. The validity of this statement appears doubtful, in view of numerous and important precedents to the contrary. ${ }^{83}$ Assuming a restatement to harmonize international law with the practice of states which draft certain categories of aliens, nationality, though no longer implying the national's exemption from military service for a foreign state, would retain conceptual utility.

\section{InTERNational Function of the Nationality Status VERSUS ITs DoMestic Deterdination}

According to the principle of the domaine réservet, the acquisition and loss of nationality is determined by domestic rather than by international law. ${ }^{84}$ Of the numerous complications ${ }^{85}$ that may result from

80. It is unlikely that any international tribunal would have recognized a Nazi claim of an alleged right to protect German Jews abroad.

81. Said the Permanent Court of International Justice in its judgment of February 28, 1939 concerning the Panevesys-Saldutiskis Railnay case: ". . . II]n the absence of a special agreement, it is the bond of nationality between the State and the individual which alone confers upon the State the right of diplomatic protection. . . ." P. C. I. J., Ser. A/B, No. 76 at 16 (1939).

82. See Hudson, The Permanent Court of International Justice, 1920-1942 (1943) 395-6; Wright, HuMan Rights aNd tHe World Order (1943) 16; Biscchop, Notionality in International La:o (1943) 37 Asr. J. INT. L. 320. However, Article 34 of the new Statute of the International Court of Justice, in part provides: "Only States may be parties in cases before the Court."

83. Koessler, Rights and Duties of Declarant Aliens (1942) 91 U. of PA. L. REv. 321, 329; Fitzhugh and Hyde, The Drafting of Neutral Aliens by lie Uniled States (1942) 36 Asr. J. I:T. L. 369; Delaney, The Alien Enemy and the Draft (1943) 12 Brooknys L. REv. 91; Kosesler, The Reformed Mexican Nationality Law (1943) 5 LA. L. REv. 420, 428-9.

84. 3 Hackmorte, Digest of International Law (1942) 1. A frequently cited dictum is the advisory opinion of the Permanent Court of International Justice, February 7, 1923, in the case of the Tunis-Morocco Nationality, P.C.I.J., Ser. B, No. 4 at 24 (1923). See also Question concerning the Acquisition of Polish Nationality, P.C.I.J., Sar. B, No. 7 at 16 (1923) and G. L. Solis v. The United Mexican States, U. S. Mlex Claims Comm., Oct. 3, 1928, Docket No. 3245, reprinted in (1929) 23 As. J.INr. L. 454. Sie also the 
this principle, the most important revolve around the "man without a country" 86 and the sujet mixte. ${ }^{87}$ These anomalies are frequently caused by divergence between the jus soli and the jus sanguinis, ${ }^{88}$ concurrently applicable to the same individual, pursuant to the principle of reserved domain, which in this respect would seem to become selfdefeating. For example, an individual born in a country applying jus sanguinis, of parents who are nationals of a country applying jus soli would acquire neither the nationality of his country of birth nor the nationality of his parents, but be born as a stateless person. Conversely, an individual born in a jus soli country of parents who are nationals of a jus sanguinis country would be born with the embarras de richesse of possessing two nationalities. Double nationality may also be caused by the divergence between two domestic laws one of which

substantially identical statement in United States v. Wong Kim Ark, 169 U. S. 649,668 (1898), referred to in Perkins v. Elg, 307 U. S. 325, 329 (1939) and discussed by Hyde, The Supreme Court of the United States as an Expositor of International Law (1937) 18 TuE British YearbooK of International Law 1, 13-4. Heinrich Triepel suggested that international law by Blankettsaetze assigned the determination of the nationality status to the several domestic laws. TRLEPEL, VöLKERRECHT Und LANDESRECHT (1899) 220. Farther reaching than those attempts at harmonizing the domestic domain principle with the gencral system of international law, rather challenging the validity of the rule itself, is the following statement by an otherwise unorthodox British writer: "It is sometimes, indeed, laid down by authors in general terms, that a state has a right to say who are its subjects; but it is hardly necessary to demonstrate the absurdity of such proposition. The common sense of nations obviously limits the power of a nation to seize at pleasure the subjects of other states as its own." Baty, The Canons of International LaW (1930) 356.

85. Kunz, Zum Problem der doppelten Staatsangehoerigkeit (1928) 2 ZEITscurirt FüR Ostrechr 401, 405, imagines the hypothetical case of an Austrian law declaring all Chinese, resident in Peking, to be Austrian nationals. Wulinas, Aspects of Modern INTERNATIONAL LAW (1939) 82, submits that "A state could hardly be entitled to enforco in its own courts as against its neighbours some peculiar doctrine of nationality which was in conflict with the general and customary rules of international intercourse. For example, an attempt by an English king in the seventeenth century to give effect to the traditional claim of the English monarchy to the Crown of France. ..." Triepel, Internationale - Regelung der Staatsangehoerigkeit, 1/1 (1929) ZeITSCHRIFT Fuer AusLAENDisches OefrentTLICHES RECHT UND VOELKERRECHT 184, 196, suggests that it would have been against international law should Great Britain, in her Naturalization Act of 1870, have conferred British nationality upon all persons speaking English as their native tongue. He even ventures to guess that such legislation would have been followed by a declaration of war by the United States.

86. "Man without a country," as used here, means a technically stateless person, and not one in the situation of the central figure in Edward E. Hale's story "The Man Without A Country" (1863). See Seckler-Hudson, Statelessness (1934).

87. See note 9 supra and SCHWARzENBERGER, op. cit. supra note 27 , at 151.

88. Roughly described, $j u s$ soli attaches the nationality status to the fact of being born in a country, jus sanguinis to the fact of being the son of a national. In this country, and some others, a mixed system prevails, as appears from an inspection of the Nationality Act of 1940, 54 Stat. 1137 (1940), 8 U. S. C. $\$ 501$. 
still sticks to the old rule "once a subject always a subject," while the naturalization practice of the other disregards that maxim. ${ }^{\circledR 3}$

The domaine réservé principle in matters of nationality law also implies that whenever, by international custom or treaty, certain rights or duties of a state with regard to a given individual flow from the latter's condition of belonging to that state, a different category of people will be included according to whether the domestic rules concerning acquisition of nationality are governed by the jus soli or the jus sanguinis.

Qualifications of the domestic domain principle have been created by way of bilateral as well as multilateral treaties. ${ }^{20}$ The existence of qualifications other than treaty provisions, has been alleged by various sources, but always in a vague language which does not represent a workable rule of practice. ${ }^{91}$ Disregard of the principle in cases where its practical consequences would be absurd could be technically justified by recourse to the public policy clause or ordre public exception, which appears to be applicable beyond the sphere of the conflict of laws in the domestic field..$^{92}$ A similar line of approach is suggested by those who point to the legal reaction against abuses of the right of sovereignty. ${ }^{.3}$

Domestic courts in several cases have shown readiness to disregard

89. SCHWARZENBERGER, op. cit. supro note 27 , at 155 .

90. Outstanding among the latter is the Conrention on Cerlain Questions Relating to lte Conflict of Nationality Laws (1930) 24 Axr. J. INT. L., SpEc. Supp. 192. However, only a few states, not including this country, have declared their adherence to it.

91. See memoranda submitted by various governments (especially the United States, Germany, and the Netherlands) in preparation of the Hague Conference of 1930, stppra note 90, 1 League of Nations, Bases of Discussion Drawn Up for tre Confere:ice: Nationality (1929) 16-8, and the pertinent statement in 23 Aur. J. Ixt. L., Spec. Surp. (1929) 24, 26. But $c f .1$ Niboyet, Traité de Droit International Privé Frasigais (1938) 101; 1 Piggotr, Nationality (1907) 4; MfcGovney, op. cit. sipra note 3, at 233. 2 Hyde, International LAw (2d rev. ed. 1945) 1066 seems to suggest a test of reasoaableness of the domestic law. In the same sense: Kunz, The VIENa Scrool AxD IsiteriaTIONAL LAW (1934) 31.

Recently, an author even went to the extreme of submitting a rather casuistic list of types of attachment which, he believes, are the factual substratum required by customary international law, as a condition for the validity of domestic law conferring the respective state's nationality upon a given category of individuals. Lessing, Los Mfomenlos De Conexión En El Derecho De Nacionalidad,(1942) 5 Revista ARgentixa de Derecho IsiterNACronal (2d Ser.) 150 et seq., 316 et seq.

92. On the applicability of the public policy clause in the field of international law, see 4 Neudayer, Internationales Verwaltungsrecht (1936) 233; Lipstein, Conflict of Laws Before International Tribunals (1943) 29 Transactions of the Grotius Socreti $51,63$.

93. Politis, Le Problème des Limitations de la Souterainets el la Thiorie de l'Abus de Droits dans les Rapports Internationaux (1925) 1 RECUEIL DES COURS DE L'ACADEuIE DE Droit International 1, 77. The German Civil Code, \$226, very narrowly defined as an abuse of a right, an exercise thereof which is done for the mere purpose of doing harm to another person. 
a foreign municipal law under which a self-exile, in spite of his own declared intention to the contrary, ${ }^{94}$ would retain his nationality of origin. ${ }^{95}$ Moreover, there have been cases where an individual, who had lost the nationality of a state under the latter's domestic law, was by a foreign court still considered its national, ${ }^{96}$ Similarly, the Expatriation Act of the United States of July 27, 1868,97 seems to announce the principle that this country will distegard any foreign nationality law under which an individual, irrespective of his American naturalization, still retains his nationality of origin..$^{98}$

A general exception to the rule of domestic domain in matters of nationality law is represented by the prohibition of compulsory naturalization, which, according to textual authority, forms part of the prevailing customary international law. This prohibition means that no state is allowed to confer its nationality upon the nationals of another state, unless the individual himself asks for such a change of his status.9 Reference may, in this connection, be made to the protests which the United States in several instances raised against Latin-American laws that had introduced automatic naturalization of certain classes of

94. For a comparative law study of the problem of renunciation or waiver of nationality see, Otten, Der Versicht Auf Die StaAtsangehörigkeit (1934). "Expatriation" has been defined as "the voluntary renunciation or abandonment of nationality and allegiance." Perkins v. Elg, 307 U. S. 325, 334 (1939). However, the normal usage of "expatriation" would seem to indicate loss of original nationality through naturalization in another country.

95. See Caignetv. Pettit, 2 Dallas (234 U.S. 1795); 3 Moore, Digest of International LAw (1906) 554; Rajdberg v. Lewi, Supreme Court of Poland, 1st Div., Oct. 31, 1927, ANNuAl Digest of Public International Law Cases (1927-8) 314-5; and the Argentine cases referred to by Lessing, op. cit. supra note 91, at 328, n. 93. But see Kurzinsliy v. Kurzinsky, Tribunal Civil de la Seine, July 5, 1939, 34 Revue Crutroue de Drolt InterNATIONAL 450, 452.

96. See the opinion of Phillimore, L. J., in Ex parte Weber (1916) 1 K. B. 280, 282-3 and of Earl Loreburn in the same case, House of Lords (1916) 1 A. C. 421, 425-6.

97. 15 StaT. 223 (1868), 8 U. S. C. $\S 800$ (1940):

98. See supra note 62. In Elk v. Wilkins, 112 U. S. 94, 107 (1884) it was said that the Act of July 27,1868 , affirmed "the right of every man to expatriate himself from one country." The Act was intended primarily as a declaration of the position of this Government toward foreign-born persons who should have obtained naturalization as citizens of the United States, and thus made it clear that this Government no longer recognized the ancient feudal principle of indissoluble allegiance. Its language, however, appears to be broad enough to include not only the reverse picture, (i.e., an American who obtains naturalization in foreign country) but also the case of a person expatriating himself from his country of origin, without simultaneously acquiring a new nationality, but rather with a view to becoming stateless. But no authority exists covering such an extended application of the Expatriation Act of 1868.

99. See Borchard, Diplomatic Protection of Citizens Abroad (1915) 535; 2 HydE, INTERNATIONAL LAW (2d rev. ed. 1945) 1088. But $c f$. Lessing, op. cil. supra note 28, at 193. 
aliens. The affected countries gradually eliminated those offensive statutory provisions. ${ }^{100}$

Customary international law has not yet developed an exception with regard to the population of a territory voluntarily or involuntarily changing its sovereign. ${ }^{101}$ This general proposition is probably true also in the case of individuals who at the time of a foreign annexation of their home territory are residing abroad and thereupon remain abroad permanently, ${ }^{102}$ The right of option, though often granted in treaties concerning cession of territories, is not established by customary international law. ${ }^{103}$

No exception from the principle of reserved domain is represented by the fact that, especially in modern times, the practice of enemy alien treatment very often disregards formal nationality, by generally exempting from that treatment certain categories of technically enemy, but really friendly, aliens, ${ }^{104}$ and on the other hand subjecting to an extraordinary regime categories of nationals who are not trusted with regard to their loyalty. ${ }^{105}$ In these cases it is not the domestic domain principle, but nationality itself which ceases to be a dominant factor.

\section{CONCLUSION}

This article has attempted to show that "nationality," as a conception of international law, does not mean any specific rights and (or)

100. The reformed nationality law of Mexico of January 19, 1934, droppad the provision contained in Art. 1/10 of the former law (Les: Vallarla of Mlay 28, 18s6). Under the latter, aliens acquiring real estate in Mexico and failing to make a declaration of retention of their nationality of origin, thereby automatically became Mevican nationals. See Koessler, op. cit. supra note 30 , at 425 .

101. But $c f$. Gettys, The Effect of Changes of Sorercignty on Nationalily (1927) 21 A2r. J. INT. L. 268 and FeILCHENFELd, Public DebTs and State Succession (1931).

102. But there is authority to the contrary. ". . . [I]t is a rule of international law that when a territory passes to a new sovereign it must, in case of doubt, be assumed that those inhabitants of the territory in question, who are not domiciled ... there do not acquire the new nationality." Peinitsch v. German State (Germany-Jugoslavia Mixed Arbitral Tribunal, 1922) Annual Digest of Public International Law Cases (1923-4) 227-8. And see Hofarannsthal and Berger, Internationall Protection of Axus Victms asd Revindication of Their Property Rights (1942) 3; Holmannsthal, Ausiro-Hungarians (1942) 36 Asr. J. INT. L. 292, 293.

103. General discussions of the right of option are: $1 \mathrm{KuNz}$, Die Vürkierrecaturene Option (1925); 2 id. (1928); Wastbaugh, A Mionograph on Plebiscites (1920).

104. Koessler, Enemy Alien Internment (1942) 57 PoL. Scr. Q. 98.

105. See Comment, Alien Enemies and Japanese Americans (1942) 51 YaLE L. J. 1316, 1336. The restrictions applied to suspect ethnological or other groups of citizens should not be confused with punitive measures taken against "Citizens who associate themselves with the military arm of the enemy government, and with its aid, suidance and direction enter this country, bent on hostile acts. . . ." United States $e x$ rel. Quirin v. Cox (the Hatspt case), 317 U. S. 1, 37-8 (1942). 
duties, nor an aggregate of either or of both, ${ }^{106}$ but is a purely formal proposition. It designates the status of a person's belonging to a state, with particular reference to international relations among states concerning this person. In a world divided into states it is the function of the nationality concept to apportion the global population among the several nations. ${ }^{107}$ Each state has both a territorial and a personal sovereignty. 108 The "nationals" of a state are those who are under its personal sovereignty, that is attached to it irrespective of the fact of their physical presence at a given moment. ${ }^{109}$ In a world without states (or if the "Cardenas doctrine" 110 were accepted as established international law) the nationality conception would lose its above-defined present meaning. ${ }^{111}$ But a realistically anticipated future world will not be able to do away with the legal concept of nationality, though it may be expected that specific rules of international law will assume paramount importance among the factors determining the acquisition or loss of nationality, thus depriving the domestic domain principle of its present controlling importance. It would also seem to be no unreasonable guess that domicile rather than birthplace or filiation may in the future be the favorite fact of attachment for the acquisition of nationality. ${ }^{112}$

106. But see the curious proposition in IsAx, Die StaATSANGEHÖRIGKeIT DER JURISTIChen Personen (1907) 42, 44-5, substantially submitting that none of the specific criteria of nationality, usually ascribed to that concept, is characteristic or essential to it, but that their aggregate constitutes the essence of nationality.

107. Burchardt, Die Organisation Der Rechtsgemeinschaft (1927) 361-2; StEIGER, DIE StaATSANGEROERIGKEIT DER HANDELSGHELISCHAFTEN (1931) 13-4.

108. "If one resolves the dualism of law and the state, if one recognizes the state as legal order, then the so-called elements of the state-territory and population-appear as the territorial and personal spheres of validity of the national legal order." Kelsen, Tho Pure Theory of Law and Analytical Jurisprudence (1941) 55 HARv. L. REv. 44, 65-6.

109. Isay, op. cit. supra note 106 , at 40 .

110. According to Brown, Cardenas Doctrine (1940) 34 Asr. J. INT. L. 300, a special commission of Mexican lawyers has thus formulated that doctrine:

"Nationality, as a personal status, has full juridical effect only within local jurisdiction. It lacks extraterritoriality, and its effects are therefore suspended in every instance when a moral and physical person moves to foreign soil. . . ."

111. This idea seems to underlie the cryptic question which Dante ascribes to the ghost of Charles Martel: "Now, say, would it be worth for man on earth, if he were not a citizen?" VIII Divina Comedia, 115-6, referred to by SpanjaARd, Nederlandsche Diplomatieite En ANDERe Bescherming IN DEN VReEMde 1795-1924 (1925) xvi.

112. See Baty, The Interconnection of Nationality and Domicile, WigMors CeLEDRATION, Legal Essays (1919) 187, 197-8, reprinted (1919) 13 ILl. L. Rev. 363, 373-4; BATY, TuE Canons of InTERNational LaW (1930) 367. 